\title{
Aphanomyces astaci Psl-genotype isolates from different Finnish signal crayfish stocks show variation in their virulence but still kill fast
}

\author{
J. Jussila ${ }^{(1), \star}$, H. Kokko(1), R. Kortet ${ }^{(2)}$, J. Makkonen ${ }^{(1)}$ \\ Received May 3, 2013 \\ Revised August 27, 2013 \\ Accepted August 28, 2013
}

Key-words: crayfish plague, noble crayfish, potent killer, Psorospermium haeckeli

\section{ABSTRACT}

We detected significant virulence differences among five tested (Psl-Puujärvi, Psl-Pyhäjärvi, Psl-Kukkia, Psl-Saimaa I and PsI-Saimaa II) Psl-genotype crayfish plague (Aphanomyces astaci) isolates against lake Mikitänjärvi noble crayfish population. The crayfish were inoculated with a dose of $300 \mathrm{~m} \cdot \mathrm{L}^{-1} \mathrm{~A}$. astaci spores in ambient water under experimental conditions. Mortalities started from four to seven days after inoculation, depending on the Psl-genotype isolate. In all the experimentally infected groups it took no more than three days for all the crayfish to die after the first mortality. The Psl-Puujärvi isolate proved to be the most virulent strain, while Psl-Kukkia was the least virulent. The average day of death for these experimental groups was fifth and ninth day, respectively. We did not discover correlation between the average day of death and gender or level of additional Psorospermium haeckeli infestation. Our results show that there are, from the practical point of view, minor virulence differences among Psl-genotype $A$. astaci isolates, and that all the tested five isolates are highly virulent. The present results emphasize the necessity to prevent all further spread of highly virulent strains of $A$. astaci to aid and shelter successful conservations attempts of the native European crayfishes.

\section{RÉSUMÉ}

Les génotypes Psl d'Aphanomyces astaci isolés de différents stocks d'écrevisses signal finlandaises montrent une variabilité dans leur virulence mais tuent toujours rapidement

Mots-clés : peste de l'écrevisse, écrevisse noble, tueur puissant, Psorospermium haeckeli

\begin{abstract}
Nous avons détecté des différences de virulence significatives entre les cinq génotypes Psl testés (Psl-Puujärvi, Psl-Pyhäjärvi, Psl-Kukkia, Psl-Saimaa I et PslSaimaa II) de la peste de l'écrevisse (Aphanomyces astaci) vis-à-vis de la population d'écrevisse noble du lac Mikitänjärvi. Les écrevisses ont été inoculées avec une dose de $300 \mathrm{~m} \cdot \mathrm{L}^{-1}$ de spores d'A. astaci dans l'eau ambiante dans des conditions expérimentales. Les mortalités ont commencé de quatre à sept jours après l'inoculation, selon le génotype Psl isolé. Dans tous les groupes infectés expérimentalement il n'a pas fallu plus de trois jours pour que toutes les écrevisses meurent après la première mortalité. L'isolat Psl-Puujärvi s'est avéré être la souche la plus virulente, tandis que PsI-Kukkia a été le moins virulent. Le nombre moyen de jours pour la mort de ces groupes expérimentaux est le cinquième et le neuvième jour, respectivement. Nous n'avons pas découvert de corrélation entre le jour moyen de décès et le sexe ou le niveau de l'infestation supplémentaire
\end{abstract}

(1) Department of Biology, Kuopio campus, The University of Eastern Finland, P.O. Box 1627, 70211 Kuopio, Suomi-Finland

(2) Department of Biology, Joensuu campus, The University of Eastern Finland, P.O. Box 111, 80101 Joensuu, Suomi-Finland

* Corresponding author: japo.jussila@uef.fi 
par Psorospermium haeckeli. Nos résultats montrent qu'il existe, du point de vue pratique, des différences de virulence mineures entre isolats de génotype Psl de $A$. astaci et que tous les cinq isolats testés sont très virulents. Les résultats actuels soulignent la nécessité de prévenir toute propagation de souches très virulentes de A. astaci pour contribuer au succès des tentatives de conservation des écrevisses européennes autochtones.

\section{INTRODUCTION}

The virulence variation of the crayfish plague (Aphanomyces astaci) strains from different epidemics had been long discussed (Huang et al., 1994; Fürst, 1995; Edgerton et al., 2004), until it was recently repeatedly documented (Makkonen et al., 2012b, 2013; Jussila et al., 2013a). In general, this disease has a bad reputation, but some $A$. astaci strains seem to show signs of avirulence (Jussila et al., 2011a; Makkonen, 2013). Certain strains of this parasite have likely adapted to their fairly recent European hosts, as the As-genotype is currently causing highly variable mortalities among native European crayfish both in laboratory experiments (Makkonen et al., 2013) and among wild populations (Jussila et al., 2011, Viljamaa-Dirks et al., 2011; Kokko et al., 2012; Svoboda et al., 2012; Caprioli et al., 2013; Kušar et al., 2013). So far, however, the evidence of virulence differences and potential evolution among Psl-genotype, or other more recently introduced $A$. astaci genotypes, has been lacking. The assumption is, that those fairly recently introduced $A$. astaci strains, that were introduced together with their original North American host crayfish species, have had less pressure and time to adapt their virulence to enable lower mortality rates among the susceptible native European crayfish populations, as has been theorized for the pathogen-host relationship to evolve in similar situations (e.g. Gandon and Michalis, 2000; Bull and Ebert, 2008). On the other hand, the hostparasite relationship of a host with long life span and a parasite with long infective periods is supposed to create diversity among both hosts and parasites (Best et al., 2010), which could thus re-balance relationship of $A$. astaci and, at least, its North American hosts in Europe. Environmental conditions could, in their part, also be a driving force of the host-parasite coevolution (Wolinska and King, 2009; Biron and Loxdale, 2013) and thus might also be affecting the aforementioned balance. The indications of a shifted balance between signal crayfish (Pacifastacus leniusculus) and $A$. astaci in Nordic countries seen as signal crayfish population collapses and severe symptoms of individual crayfish infected with $A$. astaci (Jussila et al., 2013a). The parasites could also manipulate their host's behavior or physiological processes to ensure that they could compelete their life cycle (Biron and Loxdale, 2013).

The Psl-genotype, which is one of the two known genotypes currently causing crayfish plague epidemics in Finland and other Nordic countries, has its original North American host species, the signal crayfish (P. leniusculus), present in Europe (Souty-Grosset et al., 2006). The signal crayfish has been intentionally introduced to inhabit most of the continental Europe (Westman, 2000; Souty-Grosset et al., 2006), thus assisting in the spread of the Psl-genotype crayfish plague (Unestam, 1969; Persson and Söderhäll, 1983; Diéguez-Uribeondo and Söderhäll, 1993; Diéguez-Uribeondo, 2006; Souty-Grosset et al., 2006). These A. astaci Psl-genotype strains could likely have had less pressure to adapt to novel European habitat than Asgenotype strains, since they have easy access to host habitat that is often available as a result of signal crayfish introductions (Jussila et al., 2013a). So far, this assumption has been mostly based on speculations supported by theories on general evolution of the diseases entering novel territories and infecting susceptible new hosts (Read, 1994; Regoes et al., 2000; Ebert and Bull, 2008). New invasions, in general, often result in high initial virulence that is accompanied with notable killing rates among native host candidate species (Read, 1994). In case of Psl-genotype crayfish plague, the high virulence among the native European crayfishes can be evolutionary sustained because of the continuously existing more resistant host habitat reserve, i.e. an introduced alien crayfish stock that is always present (Jussila et al., 2013a). 
The crayfish plague remains as the biggest threat to all the native European species like the noble crayfish (Astacus astacus) (Souty-Grosset et al., 2006; Jussila et al., 2013a), after the general decline of the aquatic pollution level and more ecologically friendly codes of practice in the management of the aquatic resources (EU, 2000; Jurvelius and Auvinen 2001; Tulonen et al., 2008, 2010). The signal crayfish has been more or less permanently introduced to numerous areas still inhabited by the noble crayfish (Jussila and Mannonen, 2004; Bohman et al., 2006; Johnsen et al., 2007), either according to national strategies or illegally. Crayfish plague is generally thought to be one of the main reasons for the difference in the crayfish introduction success rates between the noble crayfish and the signal crayfish (Erkamo et al., 2010). Initial reason to introduce the signal crayfish to Europe was the fact that many waterbodies were already eradicated from the noble crayfish by the first invasion of the crayfish plague. The situation has actually been further reinforced since the signal crayfish introductions have often been accompanied by the notably virulent Psl-genotype crayfish plague (Souty-Grosset et al., 2006; Jussila et al., 2013a). Furthermore, the more recently introduced $A$. astaci genotypes, namely PsI, Psll, Pc and Or (Kozubíková et al., 2011), are, if possible, an even greater threat to the native European crayfish than the originally introduced As-genotype, since unlike the As-genotype, they so far have not had to adapt to susceptible host species in Europe.

The status of the alien species, in this case both the crayfish plague and its introduced North American host crayfish species, has been debated intensively (Gherardi and Holdich, 1999). Therefore, the strategies concerning these aliens have been drafted on both national and EU level (EU, 2013). The crayfish plague and the signal crayfish have been listed as greatly harmful and harmful, respectively, in the Finnish alien species strategy (MMM, 2013). Thus, the attempts to understand the dynamics between different $A$. astaci strains, their native European crayfish hosts and an introduced alien host of North American origin are of utmost importance. The conservation actions success lies on the understanding of the dangers of chronically infected crayfish spreading high virulent strains of crayfish plague and acting as permanent sources of $A$. astaci spores.

The main aim of the study was to assess whether different isolates of Psl-genotype would differ in their virulence against the noble crayfish and whether they would all be high virulent killers. We were also interested to explore, if Lake Mikitänjärvi noble crayfish would show any resistance against this genotype, which would be different from what has been reported before in other noble crayfish populations. This interest was justified due to the fact that latent crayfish plague infection had been reported in this wild population (Jussila et al., 2011a). We also studied whether the individual crayfish being parasitized by Psorospermium haeckeli (Makkonen et al., 2013) would show different mortality rate, i.e. resistance or sensitivity, against $A$. astaci Psl-genotype. In order to fulfill our aims, we carried out a controlled infection trial under laboratory conditions.

\section{MATERIAL AND METHODS}

\section{$>$ THE EXPERIMENTAL CRAYFISH}

The Lake Mikitänjärvi (ETRS-TM35FIN coordinates N 7158870, E 604356) noble crayfish, equal numbers of both sexes in each group, were used in the infection experiment. The crayfish were obtained from a commercial trapper and kept in the holding tank system in Muuruvesi campus aquaculture facilities from early September 2012 until the commencement of the experiment in early February 2013. The crayfish were maintained, sexes separated, in two interconnected tanks in prefiltered $(5 \mu \mathrm{m})$ recirculating Lake Kallavesi water. During the holding, an ambient lake water temperature was maintained and partial water exchanges made every two weeks. Crayfish were given ad libitum sweet corn as food during the holding. The tank system contained a biofilter to lower the load from metabolic substances. Prior to the experiment, the crayfish were transported to the University of Eastern Finland RapuLatorio ${ }^{\circledR}$ (Jussila et al., 2011b) and placed in the experimental system for a two week acclimation. The crayfish sexes were determined and they were weighed $(0.1 \mathrm{~g})$ before placing them into the 


\section{Table I}

The A. astaci Psl-genotype isolates used in the experiment. The references contain further details of the isolates in question. Epidemic and isolation expressed as the year when the wild stocks started showing gross symptoms for crayfish plague or collapsed for the first time, and when the isolation was carried out by the University of Eastern Finland.

\begin{tabular}{|l|c|c|c|c|c|}
\hline Name & Code & Epidemic & Isolation & Location & Reference \\
\hline PsI-Puujärvi & UEF8866-2 & 1996 & 2003 & N 6683791, E 317391 & Makkonen et al., 2012a \\
\hline PsI-Saimaa I & Satr1 & 2007 & 2012 & N 6800998, E 555776 & Jussila et al., 2013b \\
\hline PsI-Saimaa II & Satr2 & 2007 & 2012 & N 6800998, E 555776 & Jussila et al., 2013b \\
\hline PsI-Pyhäjärvi & UEF8147-4 & 1995 & 2003 & N 6770682, E 245801 & Makkonen et al., 2012a \\
\hline PsI-Kukkia & UEF7203 & 1992 & 2003 & N 6801172, E 377743 & Makkonen et al., 2012a \\
\hline
\end{tabular}

individual $2 \mathrm{~L}$ containers of the experimental system. Crayfish feeding behaviors were monitored during acclimation and those crayfish showing decreased condition were substituted. The $P$. haeckeli infestation level for the experimental crayfish was investigated after the experiment using method described by Henttonen (1996). The crayfish were categorized by their infestation level ranking followingly: $0=$ no $P$. haeckeli; $1=1-14 P$. haeckeli and $2 \geqslant 14 P$. haeckeli counted in the sample.

\section{> THE CRAYFISH PLAGUE ISOLATES}

We used five Psl-genotype isolates to infect the experimental crayfish. The isolates were obtained from signal crayfish (P. leniusculus) which were chronic carriers of $A$. astaci. The isolates will be referred to from hereon according to epidemic: Psl-Puujärvi, Psl-Saimaa I, Psl-Saimaa II, Psl-Pyhäjärvi and Psl-Kukkia (Table I). All these strains have been isolated and maintained by the University of Eastern Finland.

\section{> PRODUCTION OF THE ZOOSPORES AND INOCULATION}

The $A$. astaci isolates, maintained in PG1-agar (Unestam, 1965), were used in the infection experiments. Details of the methods for zoospore production, modified after Cerenius et al. (1988), are explained in Makkonen et al. (2012c). The inoculation dose for the infection groups was 300 zoospores $\mathrm{m} \cdot \mathrm{L}^{-1}$.

\section{> THE EXPERIMENTAL SYSTEM}

The experimental system consisted of individual $2 \mathrm{~L}$ tanks for the crayfish and a dual sump tank system equipped with pumps and filtering system to recirculate the water. The dual sump tank system consisted of two $100 \mathrm{~L}$ tanks, with the first receiving water from the experimental crayfish tanks. The water was first prefiltered through a porous foam mat and then pumped (Biltema DP $900 \mathrm{~W}$, Sweden) through a filtering system consisting first of two filters back to back, the first being a $25 \mu \mathrm{m}$ (Polypropylene Atlas Water Filter, Atlas, Italy) and the second a $5 \mu \mathrm{m}$ filter (Spunflow QN, Dominic Hunter Technologies Ltd., England). These were followed by two parallel absolute filters (Pleatflow II, Prosep Filter Systems Ltd., England), with the filtered water ending into another $100 \mathrm{~L}$ tank and then being pumped (EHEIM Compact 1002, 6 pumps) into a pipeline distributing the water into the individual $2 L$ tanks. The filtering system used removes all the infectious agents, such as $A$. astaci spores, from the water column (Jussila et al., 2011b). The water pressure prior to the filters was monitored and the filters were replaced when the pressure exceeded 2 bar.

The water volume in the individual holding tanks was fully replaced hourly. The day and night rhythm were $12 \mathrm{~h}$ light on (fluorescent lights) and 12 off, over the night time. Water temperature was maintained stable by room air conditioning at $18 \pm 1{ }^{\circ} \mathrm{C}$. The water quality, DO-\%, 


\section{Table II}

Average day of death (mean $\pm S D$ ) of the Psl-genotype infected noble crayfish for each strain. Different superscript indicates statistically significant difference (Log Rank (Mantel-Cox), $p<0.05$ ) among the groups. All control group crayfish survived the experiment.

\begin{tabular}{|l|c|c|c|c|c|}
\hline Control & Psl-Puujärvi & Psl-Saimaa II & Psl-Saimaa I & Psl-Pyhäjärvi & Psl-Kukkia \\
\hline $\boldsymbol{n} / \boldsymbol{a}$ & $5.0 \pm 0.0^{\mathrm{d}}$ & $6.5 \pm 0.2^{\mathrm{c}}$ & $6.7 \pm 0.5^{\mathrm{b}, \mathrm{c}}$ & $8.0 \pm 0.1^{\mathrm{b}}$ & $9.0 \pm 0.2^{\mathrm{a}}$ \\
\hline
\end{tabular}

temperature and $\mathrm{pH}$, were monitored twice a week during the experiment. Gravel containing calcium was added to the sump tanks to maintain optimum water $\mathrm{pH} 7$ in the recirculating water. Water quality remained within optimal range for crayfish throughout the study. The dissolved oxygen was $88.8 \pm 10.3 \%$ ( $\min -\max , 66,1-98,9 \%)$, $\mathrm{pH}$ was $7.1 \pm 0.2$ (min-max, $6,7-7,4)$ and water temperature was $17.8 \pm 0.6^{\circ} \mathrm{C}\left(\min -\max , 17,0-18,9^{\circ} \mathrm{C}\right)$.

The crayfish were randomly divided into the experimental groups $(N=10)$, having initially equal numbers of sexes. During acclimation, five crayfish declined to feed on a regular basis and they were substituted with reserve crayfish which were feeding. Thus, finally, the control group and Psl-Saimaa II group had male to female ratio of 6:4.

Crayfish were monitored at least twice a day for behavioral symptoms indicating $A$. astaci infection (i.e., difficulties in maintaining orientation, paralysis, loosing limbs or claws) and the death. Notes were made on feeding behavior and observed symptoms.

\section{RESULTS}

\section{> CRAYFISH MORTALITY AND A. ASTACI VIRULENCE}

We observed significant differences in mortality among tested crayfish groups which were infected using different Psl-genotypes. The Psl-Puujärvi strain was the most virulent, then Psl-Saimaa I and Psl-Saimaa II, Psl-Pyhäjärvi and the least virulent strain was Psl-Kukkia (Table II, Figure 1). The differences in the average day of death between most and least virulent Psl-genotype isolates were roughly $2 \times$ (Table II). The predicted day of death in the earlier work by Makkonen et al. (2013) was, for the inoculation dose and $A$. astaci genotype used in this experiment, 5.8 days, which is thus lower than observed in this experiment, except for PslPuujärvi infected group. The control group crayfish survived the whole 12-day experiment and a two week follow-up period. The mortalities started in Psl-Puujärvi infected group four days after inoculation and in the Psl-Kukkia infected group seven days after inoculation (Figure 1). A $100 \%$ mortality rate was achieved rapidly, i.e. within three days after the first crayfish in the experimental group in question died, except for Psl-Puujärvi group in which crayfish died within two days.

\section{> PSOROSPERMIUM HAECKELI}

All the experimental crayfish were infested with $P$. haeckeli. The crayfish in experimental groups Psl-Puujärvi, Psl-Saimaa II, Psl-Pyhäjärvi and control group had both level 1 and 2 infestation, while Psl-Saimaa and Psl-Kukkia had only level 2 infestation. We did not observed differences in the average day of death among the two infestation levels within experimental groups (Mann-Whitney U-test, $p>0.05$ in all valid cases).

\section{DISCUSSION}

We have shown significant, but from the practical point of view minor, differences in virulence among several highly lethal Psl-genotype crayfish plague $(A$. astaci) strains isolated from the signal crayfish ( $P$. leniusculus) of Finnish origin. During the laboratory trials the mortality rates, 


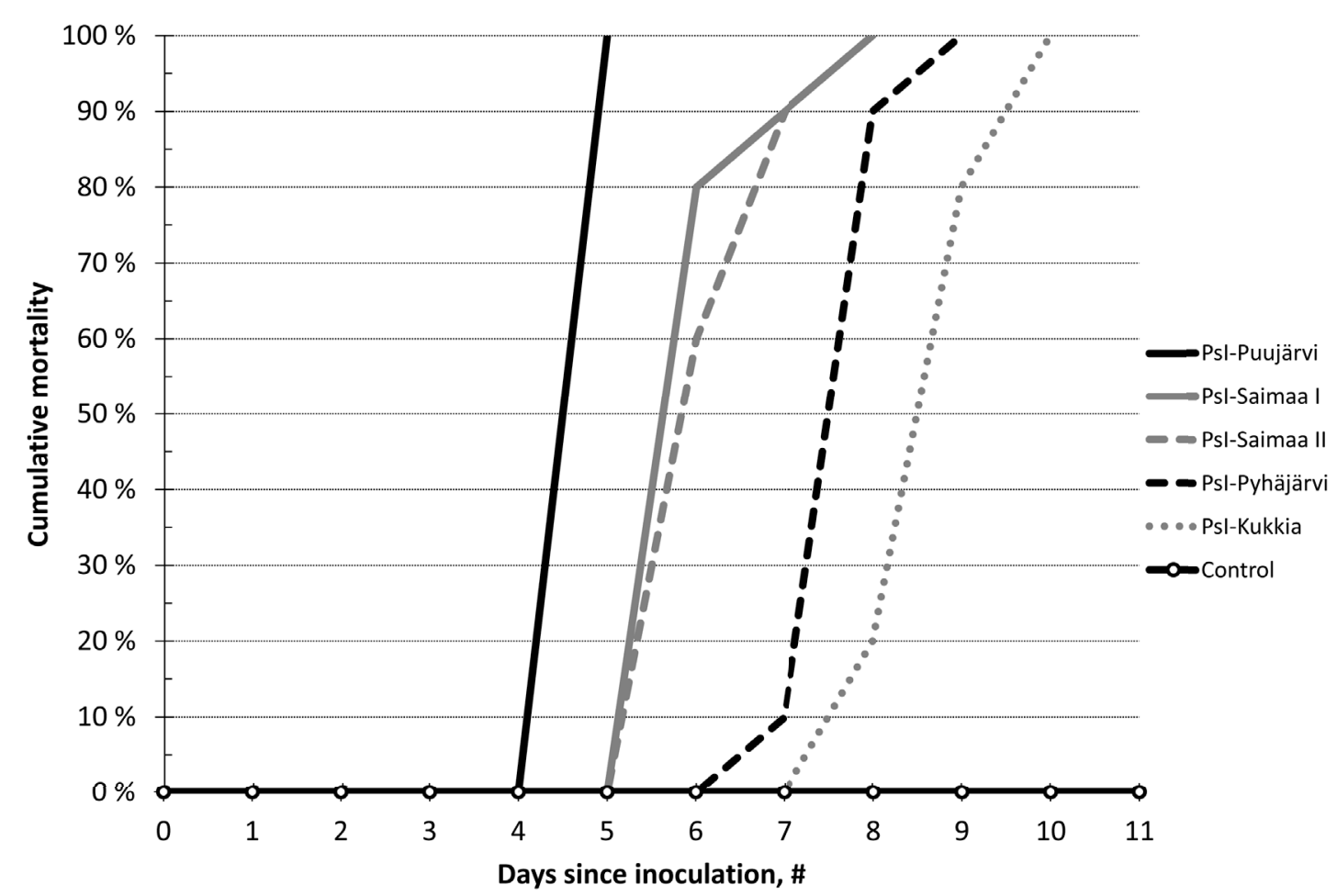

\section{Figure 1}

The mortality rates among the noble crayfish groups inoculated using different Psl-genotype isolates from Finland and the control crayfish group. The inoculation dose was 300 spores per $m \cdot L^{-1}$. Statistically significant differences were observed among isolates from different geographical locations, from most virulent to least virulent: Psl-Puujärvi > Psl-Saimaa I = Psl-Saimaa II > Psl-Pyhäjärvi > Psl-Kukkia (Log Rank (Mantel-Cox), $p<0.05)$.

expressed as the average day of death of the experimental group, varied from five to nine days. This means roughly $100 \%$ variation when the most virulent isolate killing rate was compared to the least virulent isolate. We have to emphasize that all the crayfish died in every infected group and mortalities happened in little more than a week after the inoculation, in contrast to zero mortality in control group. This would have meant an instant and total eradication of a noble crayfish population in wild after an infection.

Our results regarding the Psl-genotype $A$. astaci killing rate are in line with our previous findings on the virulence of the Psl-genotype (Jussila et al., 2011b; Makkonen et al., 2012b; Makkonen et al., 2013), and, furthermore, there are also other reports indicating high virulence in the $A$. astaci genotypes that have been introduced with alien crayfish from North America (Diéguez-Uribeondo and Söderhäll 1993; Bohman et al., 2006; Souty-Grosset et al., 2006; Aquiloni et al., 2011). We also verified, while in a more narrow scale, the findings on the variable virulence of different crayfish plague isolates within genotype level, which have largely been previously obtained from studies on As-genotype (Makkonen et al., 2011; Makkonen et al., 2012b; Jussila et al., 2013a). On the other hand, we have previously observed a delayed mortality among Psl-Puujärvi infected Lake Mikitänjärvi noble crayfish (Makkonen et al. 2013; Makkonen, 2013), but reasons for the mortality rate differences among different experiments have not been analyzed. The possible reasons for this between-experiment variation could be differences in experimental crayfish condition among the different experiments, especially when crayfish from the same wild stock have been used, or crayfish plague spores behaving differently during different experiments due to minor differences during the spore production process.

On the other hand, we did not find the Lake Mikitänjärvi noble crayfish to be more vulnerable to crayfish plague infection when infested also with $P$. haeckeli, while such weakening of the 
immune system has earlier been reported in the signal crayfish (Thörnqvist and Söderhäll, 1993). In the future, the effects of multiple infestations to the immune system status in freshwater crayfish should be thoroughly studied.

We observed clear behavioral symptoms indicating late stages of the infection, similarly to our previous laboratory studies (Makkonen, 2013). These symptoms include 1) crayfish starting to scratch their bodies with chelae and 2) lost limbs a day before death. Less than a day before death, the experimental crayfish usually lost their balance and could not maintain normal upright position. The behavioral symptoms were similar in all groups in this study and the initiation of the scratching was the point of no return, leading to death of the crayfish. Based on our observations, most of the As-genotype infected crayfish in our previous studies experienced a lengthy catatonic stage before dying (Makkonen, 2013), which is different from what was observed during this or our previous studies using the Psl-genotype for the noble crayfish challenging (Makkonen et al., 2012b, 2013).

The differences observed in the virulence among the tested Psl-genotype isolates in this study might be an indication of what we have reported before on the differences among Psl-genotype isolates' chitinase gene (Makkonen et al., 2012b). We have already observed differences on genome level within the Psl-genotype. These differencies could indicate the presently detected virulence differences. The previously observed differences in chitinase genes were more pronounced within As-genotype compared to the combined Ps-genotype, i.e. in both Psl and Psll-genotypes (Makkonen et al., 2012b), with the assumption that those differences could reflect also virulence differences. The differences in Psl-genotype chitinase genes, even though evident, were minor compared to As-genotype (Makkonen et al., 2012b), which has also shown wider virulence variation in previous studies compared to what we observed with Psl-genotype in this study (Makkonen, 2013). Chitinase production has been claimed to be adaptation to parasitic life style and one of the virulence factors (Unestam, 1966; Hochwimmer et al., 2009).

The reports of $A$. astaci adaptation to the European crayfish hosts (Jussila et al., 2011; Viljamaa-Dirks et al., 2011; Kokko et al., 2012; Svoboda et al., 2012; Kušar et al., 2013) are most probably all concerning As-genotype adaptation. The 150 year history in Europe, with high selection pressure, has caused a rather rapid co-evolution of both the host and the pathogen. The drive to less virulent parasite-like life style is not as strong in case of the Pslgenotype tested in this study, as it is expected to be in As-genotype (Makkonen et al., 2012a). Taken together, the recent results give a strong signal about the case of an invading disease, that can use resistant host habitat species as a reserve, but simultaneuously being detrimental to those species susceptible to the disease, in this case crayfish native to Europe. Thus, the policies driving for the conservation of the native species and actions against harmful alien species are urgently needed. The attempt to implement a common alien species strategy within European Union is important, and tough measures are needed to prevent the spread of the aliens carrying high virulent strains of the crayfish plague.

We conclude, that the $A$. astaci Psl-genotypes, that were introduced to Europe with the signal crayfish, are high virulent, and that the tested isolates do not show signs of adaptation to co-existence with one of the threatened native European crayfish, the noble crayfish. Thus, the Psl-genotype crayfish plague been frequently carried with the signal crayfish is an utmost threat to the noble crayfish stocks and thus the spread of the alien crayfish and crayfish plague should be prevented. The conservation attempts of the European crayfish can succeed only, if the dilemma of the socioeconomic benefits of the alien species over native species and the negative impact on alien species to native species is thoroughly considered and understood.

\section{ACKNOWLEDGEMENTS}

This research has been supported by the strategic funding of the University of Eastern Finland (Innovative Research Initiative project) and by the Ministry of Forestry and Agriculture of Finland. We are thankful to Mr. Hobo Kukkonen for assistance during the experiments. 
Mr. Markku Niskanen (Moisiovaara, Hyrynsalmi) kindly provided the lake Mikitänjärvi noble crayfish. Professor Anssi Vainikka gave valuable comments during the process.

\section{REFERENCES}

Aquiloni L., Martín M.P., Gherardi F. and Diéguez-Uribeondo J., 2011. The North American crayfish Procambarus clarkii is the carrier of the oomycete Aphanomyces astaci in Italy. Biol. Invasions, 13, 359-367.

Best A., White A., Kisdi É., Antonovics J., Brockhurst M.A. and Boots M., 2010. The evolution of hostparasite range. Am. Nat., 176, 63-71.

Biron D.G. and Loxdale H.D., 2013. Host-parasite molecular cross-talk during the manipulative process of a host by its parasite. J. Exp. Biol., 216, 148-160.

Bohman P., Nordwall F. and Edsman L., 2006. The effect of the large-scale introduction of signal crayfish on the spread of crayfish plague in Sweden. Bull. Fr. Pêche Piscic., 380-381, 1291-1302.

Bull J.J. and Ebert D., 2008. Invasion thresholds and the evolution of nonequilibrium virulence. Evol. Appl., 1, 172-182.

Ebert D. and Bull J.J., 2008. The evolution and expression of virulence. In: Stearns S.C. and Koella J.C. (eds.), Evolution in health and disease, Oxford University Press, Oxford, 153-167.

Caprioli R., Carnigi D., Marcacci M., Cammá C., Giansante C. and Ferri N., 2013. Self-limiting outbreak of crayfish plague in an Austropotamobius pallipes population of a river basin in the Abruzzi region (central Italy). Dis. Aquat. Organ., 103, 149-156.

Cerenius L., Söderhäll K., Persson M. and Ajaxon R., 1988. The crayfish plague fungus, Aphanomyces astaci: diagnosis, isolation and pathobiology. Freshw. Crayfish, 7, 131-144.

Diéguez-Uribeondo J. and Söderhäll K., 1993. Procambarus clarkii Girard as a vector for the crayfish plague fungus, Aphanomyces astaci Schikora. Aquacult. Res., 24, 761-765.

Diéguez-Uribeondo J., 2006. The dispersion of the Aphanomyces astaci-carrier Pacifastacus leniusculus by humans represents the main cause of disappearance of the indigenous crayfish Austropotamobius pallipes in Navarra. Bull. Fr. Pêche Piscicult., 380-381, 1303-1312.

Edgerton B.F., Henttonen P., Jussila J., Mannonen A., Paasonen P., Taugbøl T., Edsman L. and Souty-Grosset C., 2004. Understanding the causes of disease in European crayfish. Conserv. Biol. 18, 1466-1474.

Erkamo E., Ruokonen T., Alapassi T., Ruokolainen J., Järvenpää T., Tulonen J. and Kirjavainen J., 2010. Evaluation of crayfish stocking success in Finland. Freshw. Crayfish, 17, 77-83.

EU, 2000. Directive 2000/60/EC of the European Parliament and of the Council of 23 October 2000 establishing a framework for Community action in the field of water policy. Official J. Eur. Communities, L 327, $72 \mathrm{p}$.

EU, 2013 Our life insurance, our natural capital: an EU biodiversity strategy to 2020. http://ec.europa. eu/environment/nature/biodiversity/comm2006/2020.htm. Visited 25.4.2013.

Fürst M., 1995. On the recovery of Astacus astacus L. populations after an epizootic of the crayfish plague (Aphanomyces astaci Shikora). Freshw Crayfish, 8, 565-576.

Gandon S. and Michalakis Y., 2000. Evolution of parasite virulence against qualitative or quantitative host resistance. Proc. Royal Soc. London, 267, 985-990.

Gherardi F. and Holdich D.M. (Eds.), 1999. Crayfish in Europe as alien species. How to make the best of a bad situation? A.A. Balkema, Rotterdam, 299 p.

Henttonen P., 1996: The parasite Psorospermium in freshwater crayfish. Doctoral dissertation. Department of Applied Zoology \& Veterinary Medicine, University of Kuopio, Finland, 78 p.

Huang T-S., Cerenius L. and Söderhäll K., 1994. Analysis of genetic diversity in the crayfish plague fungus, Aphanomyces astaci, by random amplification of polymorphic DNA. Aquaculture, 126, $1-9$.

Hochwimmer G., Tober R., Ribars-Reiter R., Licek E. and Steinborn R., 2009. Identification of two GH18 chitinase family genes and their use as targets for detection of the crayfish-plague oomycete Aphanomyces astaci. BMC Microbiol., 9, 184.

Johnsen S.I., Taugbøl T., Andersen O., Museth J. and Vrålstad T., 2007. The first record of the nonindigenous signal crayfish Pasifastacus leniusculus in Norway. Biol. Invasions, 9, 939-941. 
Jurvelius J. and Auvinen H., 2001. Fish habitat science and management in Finnish freshwaters. Aquatic Ecosyst. Health, 4, 413-421.

Jussila J. and Mannonen A., 2004. Crayfisheries in Finland, a short overview. Bull. Fr. Pêche Piscic., 372-373, 263-273.

Jussila J., Makkonen J., Vainikka A., Kortet R. and Kokko H., 2011a. Latent crayfish plague (Aphanomyces astaci) infection in a robust wild noble crayfish (Astacus astacus) population. Aquaculture, 321, 17-20.

Jussila J., Makkonen J. and Kokko H., 2011b. Peracetic acid (PAA) treatment is an effective disinfectant against crayfish plague (Aphanomyces astaci) spores in aquaculture. Aquaculture, 320, 37-42.

Jussila J., Makkonen J., Vainikka A., Kortet R. and Kokko H., 2013a. Crayfish plague dilemma: how to be a corteous killer? Boreal Environ. Res., in print.

Jussila J., Tiitinen V., Fotedar, R. and Kokko H., 2013b. A simple and efficient cooling method for postharvest transport of the commercial crayfish catch. Freshw. Crayfish, 19, 15-19.

Kokko H., Koistinen L., Harlioğlu M.M., Makkonen J., Aydın H. and Jussila J., 2012. Recovering Turkish narrow clawed crayfish (Astacus leptodactylus) populations carry Aphanomyces astaci. Knowl. Managt. Aquatic Ecosyst., 404, 1-7.

Kozubíková E., Viljamaa-Dirks S., Heinikainen S. and Petrusek A., 2011. Spiny-cheek crayfish Orconectes limosus carry a novel genotype of the crayfish plague pathogen Aphanomyces astaci. J. Invertebr. Pathol., 108, 214-216.

Kušar D., Vrezec A., Matjaž O. and Jenčič V., 2013. Aphanomyces astaci in wild crayfish populations in Slovenia: first report of persistent infection in a stone crayfish Austropotamobius torrentium population. Dis. Aquat. Organ., 103, 157-169.

Makkonen J., 2013. The crayfish plague pathogen Aphanomyces astaci - genetic diversity and adaptation to the host species. Doctoral Dissertation. The Department of Biology, University of Eastern Finland, Kuopio, 67 p.

Makkonen J., Jussila J., Henttonen P. and Kokko H., 2011. Ribosomal ITS regions of crayfish plague (Aphanomyces astaci) strains have internal and external variation. Aquaculture, 311, 48-53.

Makkonen J., Jussila J. and Kokko H., 2012a. The diversity of the pathogenic Oomycete (Aphanomyces astaci) chitinase genes within the genotypes indicate adaptation to its hosts. Fungal Genet. Biol., 49, 635-642.

Makkonen J., Jussila J., Kortet R., Vainikka A. and Kokko H., 2012b. Differing virulence of Aphanomyces astaci isolates and elevated resistance of noble crayfish Astacus astacus against crayfish plague. Dis. Aquat. Organ., 102, 129-136.

Makkonen J., Strand D., Vrålstad T., Kokko H. and Jussila J., 2012c. Quantity and timing of Aphanomyces astaci zoospore release from the noble crayfish suffering from crayfish plague. Vet. Mic., 162, 750-755.

Makkonen J., Jussila J., Kortet R., Vainikka A. and Kokko H., 2013. Resistance and dose-dependent mortality to the crayfish plague (Aphanomyces astaci) in the noble crayfish (Astacus astacus). J. Invertebr. Pathol., submitted.

MMM, 2013. Vieraslajit Suomessa. http://www.mmm.fi/fi/index/etusivu/ymparisto/ luonnonmonimuotoisuus/vieraslajit.html. Visited 15.4.2013. In Finnish.

Persson M. and Söderhäll K., 1983. Pacifastacus leniusculus (Dana) and its resistance to the parasitic fungus Aphanomyces astaci Schikora. Freshw. Crayfish, 5, 292-298.

Read A.F., 1994. The evolution of virulence. Trends Microbiol., 2, 73-75.

Regoes R.R., Nowak M.A. and Bonhoeffer S., 2000. Evolution of virulence in a heterogeneous host population. Evolution, 54, 64-71.

Souty-Grosset C., Holdich D.M., Noël P.Y., Reynolds J.D. and Haffner P. (eds.), 2006. Atlas of crayfish in Europe, Muséum national d'Historie naturelle, Paris, $187 \mathrm{p}$.

Svoboda J., Kozubíková E., Kozák P., Kouba A., Bahadir Koca S., Diler Ö., Diler I., Policar T. and Petrusek A., 2012. PCR detection of the crayfish plague pathogen in narrow-clawed crayfish inhabiting Lake Eđirdir in Turkey. Dis. Aquat. Organ., 98, 255-259.

Thörnqvist P-O. and Söderhäll K., 1993: Psorospermium haeckeli and its interaction with the crayfish defence system. Aquaculture, 117, 205-213.

Tulonen J., Erkamo E., Jussila J. and Mannonen A., 2008. Shelter and depth use of adult noble crayfish (Astacus astacus (L.)) and signal crayfish (Pacifastacus leniusculus (Dana)) in the presence of a predator. Freshw. Crayfish, 16, 93-96. 
Tulonen J., Erkamo E., Mannonen A. and Jussila J., 2010. The mortality of juvenile noble crayfish, Astacus astacus, under conditions of water level regulation and predator pressure. Freshw. Crayfish, 17, 135-139.

Unestam T., 1965. Studies on the crayfish plague fungus Aphanomyces astaci I. Some factors affecting growth in vitro. Physiol. Plantarum, 18, 483-505.

Unestam T., 1969. Resistance to the crayfish plague in some American, Japanese and European crayfishes. Rep. Inst. Freshw. Res. Drottningholm, 49, 202-209.

Viljamaa-Dirks S., Heinikainen S., Nieminen M., Vennerström P. and Pelkonen S., 2011. Persistent infection by crayfish plague Aphanomyces astaci in a noble crayfish population - A case report. Bull. Eur. Ass. Fish Pathol., 31, 182-188.

Westman K., 2000. Comparison of the crayfish Pacifastacus leniusculus Dana, a species introduced into Finland, with the native species, Astacus astacus L., in allopatry and sympatry. PhD Dissertation. University of Helsinki, Helsinki, Finland, $50 \mathrm{p}$.

Wolinska J. and King K.C., 2009. Environment can alter selection in host-parasite interactions. Cell, 25, 236-244. 